\title{
COVID-19 Vaccines - A Narrative Review
}

\author{
Saurav Deka', Farah Iram², Niveditha Hariharan², Betina Chandolia', \\ Aparajita Dubey ${ }^{2}$
}

${ }^{1}$ AVP, Real World Evidence, THB, India ${ }^{2}$ Medical Writer, Real World Evidence, THB, India

Corresponding Author: Betina Chandolia

\begin{abstract}
Since the pandemic started, various clinical trials have been going on to develop COVID vaccines. Vaccines which have passed the clinical trials include live attenuated vaccines, inactivated vaccines, protein subunit vaccines, virus like particles vaccines, viral vector vaccines, and nucleic acid vaccines. There are several vaccines in phase III and IV trials, and more than ten vaccines have been approved or authorized. Most of these vaccines are efficacious and safe. However, there are various pros and cons of these vaccines. This review explains how these vaccines have been developed, their mechanism of action, advantages, and disadvantages of these vaccines, along with costing and post vaccination challenges.
\end{abstract}

Keywords: Covid-19 vaccines, efficacy, safety, post-vaccination challenges

\section{INTRODUCTION}

The COVID 19 has taken the whole world by storm. Every region of the world is trying to develop a successful vaccine to treat COVID 19 at the earliest. Various trials have already been carried out, and different vaccines have become available in different countries. Before understanding how these vaccines work, let us briefly overview the structure of the SARS-CoV-2 virus. The SARS-CoV-2 virus consists of four structural proteins: Spike $(\mathrm{S})$, an envelope (E), hemagglutinin Esterase (HE), membrane (M), and a nucleocapsid (N) Protein.

\section{Development of COVID Vaccines}

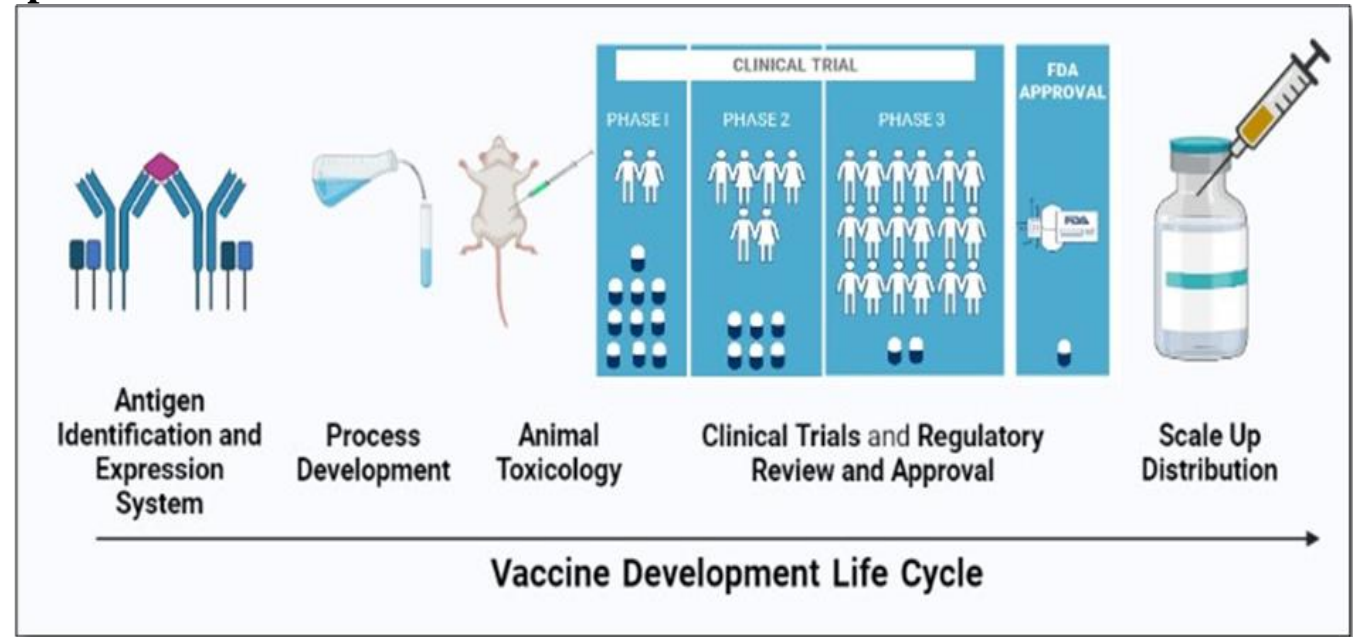

Figure 1: shows the Life cycle of vaccine development. "Created with BioRender.com"

Majorly three types of coronavirus vaccines are in development, Protein-based, Viral vectors, and mRNA based ${ }^{2}$. The primary aim of all vaccines is to expose the body to an antigen that won't cause disease but will elicit an immune response against 
the virus ${ }^{3}$. The life cycle of vaccine development is shown in Figure 1

\section{The Life cycle of SARS-CoV2}

The surface spike (S) protein of SARS-CoV-2 binds to angiotensinconverting enzyme 2 (ACE2) and enters host cells. Subsequently, viral genomic RNA is released and translated into viral polymerase proteins. Subgenomic(-) RNAs are synthesized and used as a template to create subgenomic(+) messenger RNAs in this step (mRNAs). In the cytoplasm, the nucleocapsid $(\mathrm{N})$ structural protein and viral
RNA are replicated, transcribed, and synthesized. In contrast, in the endoplasmic reticulum (ER), other viral structural proteins such as the $\mathrm{S}$ protein, membrane (M) protein, and envelope (E) protein are transcribed and then translated.At the ERGolgi intermediate compartment (ERGIC), the structural proteins are assembled into the nucleocapsid and viral envelope to form a mature virion. The budding virion is then released from the host cell ${ }^{4}$.There are various approaches to develop COVID 19 vaccines $^{5}$, as depicted in Figure 2.

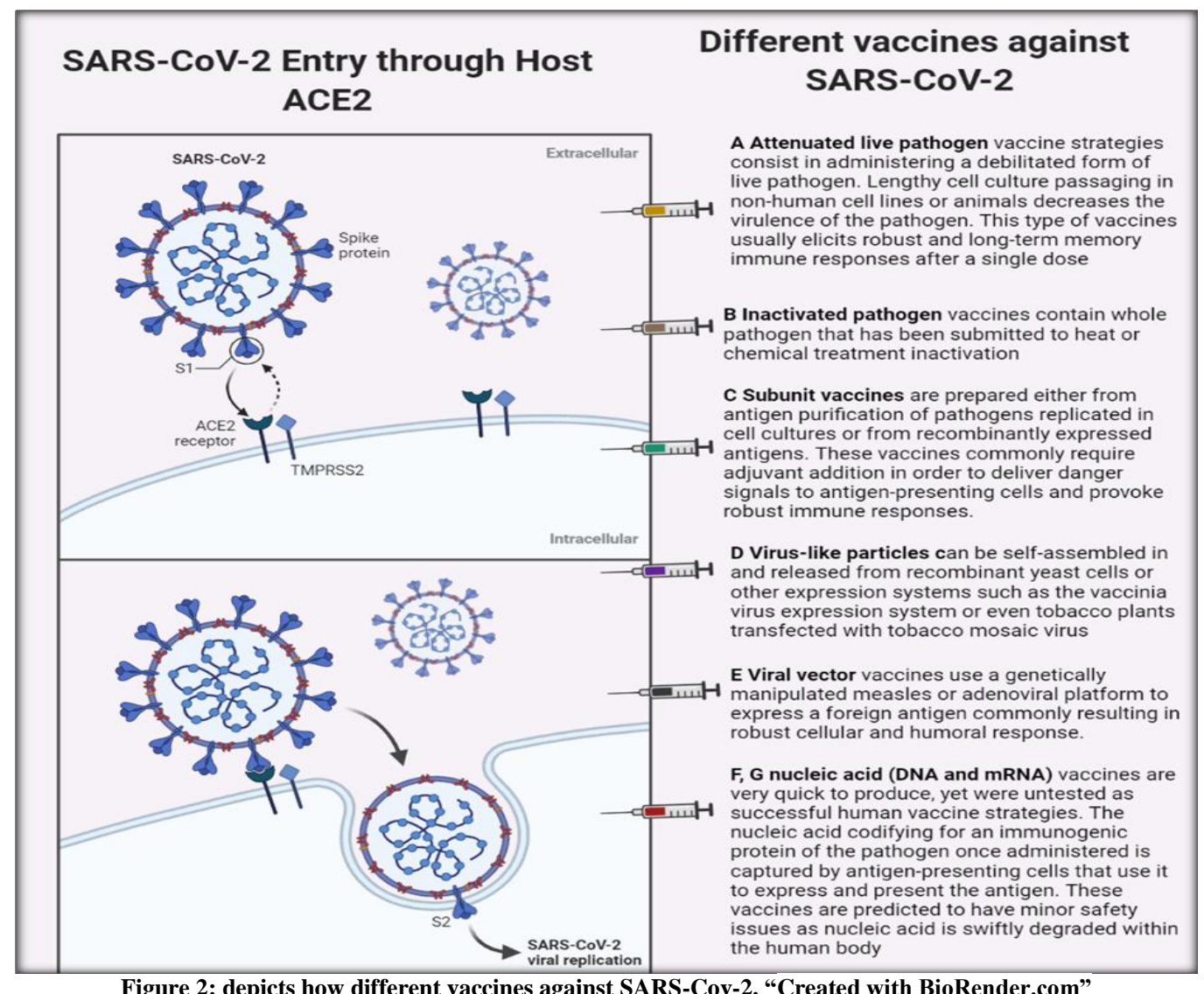

\section{How COVID Vaccines Work?}

COVID vaccines produce an immunogen which is an antigen that can elicit an immune response. It trains the immune system to identify the pathogen when it is confronted naturally by triggering: $\mathrm{CD} 4+$ helper $\mathrm{T}$ cells that in turn stimulate B-cells to generate neutralizing antibodies specific to the virus and CD8+ cytotoxic $\mathrm{T}$ cells to identify and kill cells affected by the virus ${ }^{6-9}$.

\section{Advantages and Disadvantages of Vaccines available in the healthcare field}

The advantages and disadvantages of vaccines based upon the type of vaccine are mentioned in Table $1^{10}$. 
Table 1: depicts the advantages and disadvantages of vaccines based on vaccine type

\begin{tabular}{|c|c|c|c|}
\hline Vaccine type & Description & Pros & Cons \\
\hline $\begin{array}{l}\text { Live } \\
\text { attenuated } \\
\text { vaccine }\end{array}$ & $\begin{array}{l}\text { Vaccines contain viruses modified to hamper their } \\
\text { replication and infection rate. }\end{array}$ & $\begin{array}{l}\text { Rapid development, } \\
\text { induce high immune } \\
\text { response, mimic } \\
\text { natural infection, create } \\
\text { cross reactivity }\end{array}$ & $\begin{array}{l}\text { Phenotypic or genotypic reversion, } \\
\text { not suitable to all age groups, can } \\
\text { revert and cause disease, might be } \\
\text { harmful in immunocompromised. }\end{array}$ \\
\hline $\begin{array}{l}\text { Inactivated } \\
\text { Vaccine }\end{array}$ & $\begin{array}{l}\text { Inactivated vaccines are constituted by a virus treated } \\
\text { physiochemically to inhibit its pathogenicity. Upon } \\
\text { injection, the inactivated viruses are engulfed by antigen } \\
\text { processing cells (APCs) and different epitopes are } \\
\text { presented to the immune system }\end{array}$ & $\begin{array}{l}\text { Easy to prepare, safe, } \\
\text { high-titre neutralizing } \\
\text { antibodies, very stable }\end{array}$ & $\begin{array}{l}\text { possible cause of hypersensitivity, } \\
\text { short memory }\end{array}$ \\
\hline $\begin{array}{l}\text { Protein } \\
\text { subunit } \\
\text { vaccine: }\end{array}$ & $\begin{array}{l}\text { The subunit vaccines are composed of viral surface } \\
\text { proteins formulated with adjuvants to elicit strong } \\
\text { neutralizing antibody responses. Once injected, the } \\
\text { proteins are engulfed by the APCs. }\end{array}$ & $\begin{array}{l}\text { High safety, consistent } \\
\text { production, can induce } \\
\text { cellular and humoral } \\
\text { immune response, do } \\
\text { not cause disease }\end{array}$ & $\begin{array}{l}\text { High cost, lower immunogenicity, } \\
\text { require repeated dose and } \\
\text { adjuvants, short memory }\end{array}$ \\
\hline $\begin{array}{l}\text { Virus Like } \\
\text { Particles } \\
\text { (VLP) } \\
\text { vaccine: }\end{array}$ & $\begin{array}{l}\text { They are constituted by one or more viral proteins } \\
\text { assembled into a particle without viral genetic material. } \\
\text { As such, these viral particles do not cause a disease while } \\
\text { having a better uptake profile and more efficient } \\
\text { circulation to the lymph nodes. Thus, they produce } \\
\text { stronger immune responses }\end{array}$ & $\begin{array}{l}\text { Increased uptake by } \\
\text { lymph node, do not } \\
\text { cause disease }\end{array}$ & $\begin{array}{l}\text { Dependant on efficient expression } \\
\text { platform, difficult to make VLP } \\
\text { stable in long term }\end{array}$ \\
\hline $\begin{array}{l}\text { Viral Vector } \\
\text { vaccine }\end{array}$ & $\begin{array}{l}\text { Recombinant virus vaccines composed of viral vectors } \\
\text { containing proteins from the target virus. It completely } \\
\text { mimics natural viral infection, creating a strong immune } \\
\text { response against it }\end{array}$ & $\begin{array}{l}\text { Specific delivery tool } \\
\text { required, } \quad \text { Lower } \\
\text { immune responses, } \\
\text { repeated doses may } \\
\text { cause toxicity }\end{array}$ & $\begin{array}{l}\text { May induce prior immunity to } \\
\text { vector }\end{array}$ \\
\hline $\begin{array}{l}\text { mRNA } \\
\text { Vaccine }\end{array}$ & $\begin{array}{l}\text { These vaccines deliver RNA coding targeting viral } \\
\text { proteins into human cells. Then, they will produce viral } \\
\text { proteins and, if a polymerase is encoded, also replicate } \\
\text { themselves. This way RNA-based vaccines mimic } \\
\text { ongoing viral infection including toll-like receptor } \\
\text { activation and IFN production. Such vaccines containing } \\
\text { different versions of mRNA for the spike protein have } \\
\text { been developed. }\end{array}$ & $\begin{array}{l}\text { Easy to design, higher } \\
\text { degree of adaptability, } \\
\text { induce strong immune } \\
\text { response }\end{array}$ & $\begin{array}{l}\text { Highly unstable, safety issue, low } \\
\text { immune priming if efficacy of } \\
\text { delivery is low }\end{array}$ \\
\hline $\begin{array}{l}\text { DNA } \\
\text { Vaccine }\end{array}$ & $\begin{array}{l}\text { DNA vaccines are appropriate for emerging infectious } \\
\text { diseases because they allow for the rapid design of } \\
\text { multiple candidates for novel antigens they are directly } \\
\text { injected or otherwise inoculated into recipients }\end{array}$ & $\begin{array}{l}\text { Easy to design and } \\
\text { scale up, high safety, } \\
\text { high-titer neutralizing } \\
\text { antibodies }\end{array}$ & $\begin{array}{l}\text { Specific delivery tool required, } \\
\text { Lower immune responses, } \\
\text { repeated doses may cause toxicity. }\end{array}$ \\
\hline
\end{tabular}

Table 2: depicts the name of vaccine, country of origin, dose, administration, advantages and disadvantages of each vaccine

\begin{tabular}{|c|c|c|c|c|}
\hline $\begin{array}{c}\text { S } \\
\text { No. }\end{array}$ & $\begin{array}{l}\text { Vaccine Name and } \\
\text { Country of Origin }\end{array}$ & $\begin{array}{l}\text { Vaccine Dose and } \\
\text { Administration }\end{array}$ & Advantages & Disadvantages \\
\hline 1 & Moderna, US & $\begin{array}{l}\text { Dose: } 100 \mu \mathrm{g}, \text { Two doses- } \\
28 \text { days apart }\end{array}$ & $\begin{array}{ll}- & \text { Simple } \\
\text { standardization } \\
- & \text { Simple } \\
& \text { manufacturing } \\
- & \text { Easy scaling up }\end{array}$ & - $\quad$ Storage and Transport difficulties \\
\hline 2 & Pfizer BioNTech, US & $\begin{array}{l}\text { Dose: } 30 \mu \mathrm{g}, \text { Two doses- } \\
21 \text { days apart }\end{array}$ & $\begin{array}{ll}- & \text { Simple } \\
\text { standardization } \\
- & \text { Simple } \\
& \text { manufacturing } \\
\text { - } & \text { Easy scaling up }\end{array}$ & - $\quad$ Storage and Transport difficulties \\
\hline 3 & AstraZeneca, UK & $\begin{array}{l}\text { Dose: } 0.22 \mathrm{ml} \text { or } 0.5 \mathrm{ml} \text {, } \\
\text { Two doses- } 4-12 \text { weeks } \\
\text { apart }\end{array}$ & $\begin{array}{l}\text { - } \quad \begin{array}{l}\text { Better immune } \\
\text { response }\end{array}\end{array}$ & - $\quad$ Complex manufacturing \\
\hline 4 & Sputnik V, Russia & $\begin{array}{l}\text { Dose: } 0.5 \mathrm{ml} \text { or } 1.0 \mathrm{ml} \text {, } \\
\text { Two doses- } 21 \text { days apart }\end{array}$ & $\begin{array}{ll}- & \begin{array}{l}\text { Better immune } \\
\text { response }\end{array}\end{array}$ & - $\quad$ Complex manufacturing \\
\hline 5 & $\begin{array}{ll}\text { Janssen, } & \text { The } \\
\text { Netherlands, US } & \end{array}$ & $\begin{array}{l}\text { Dose: } 1 \mathrm{ml} \\
\text { One dose }\end{array}$ & $\begin{array}{ll}- & \begin{array}{l}\text { Better immune } \\
\text { response }\end{array}\end{array}$ & - $\quad$ Complex manufacturing \\
\hline 6 & Sinovac, China & 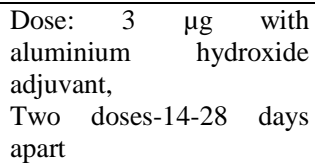 & 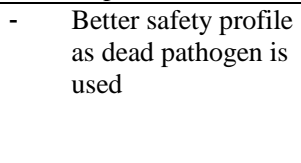 & $\begin{array}{l}\text { Requirement of additional adjuvants as } \\
\text { chemically inactivated pathogen may } \\
\text { lose immunogenicity }\end{array}$ \\
\hline 7 & Sinopharm, China & $\begin{array}{lc}\text { Dose: } 4 & \mu \mathrm{g} \text { with } \\
\text { aluminium } & \text { hydroxide } \\
\text { adjuvant, } & \\
\text { Two doses-21 days apart }\end{array}$ & $\begin{array}{l}\text { - } \quad \text { Better safety profile } \\
\text { as dead pathogen is } \\
\text { used }\end{array}$ & 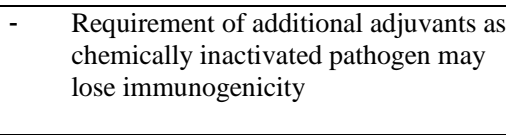 \\
\hline 8 & Covaxin, India & $\begin{array}{l}\text { Dose: } 0.5 \mathrm{ml} \text {, } \\
\text { Two dose- } 28 \text { days apart }\end{array}$ & 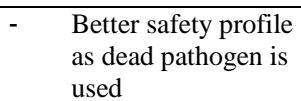 & $\begin{array}{l}\text { Requirement of additional adjuvants as } \\
\text { chemically inactivated pathogen may } \\
\text { lose immunogenicity }\end{array}$ \\
\hline
\end{tabular}


The vaccines that are available for use in the healthcare market, their administration, dose, advantages, and disadvantages of each vaccine are mentioned in the Table $2^{11,12}$.

\section{Challenges after Vaccination}

Though the focus of developing vaccines is to provide immunity against the virus, the challenges experienced after vaccination cannot be ignored. One of the major challenges some individuals have come across is getting COVID even after getting the vaccination. This could be due to two reasons, either the body is still in the phase of developing immunity against the virus, or the body has been attacked by mutant strain of the COVID virus ${ }^{13}$. Graph 1 shows the number of individuals that have been vaccinated for each dose and the number of individuals who got infected after each dose for Covishield and Covaxin ${ }^{14}$.

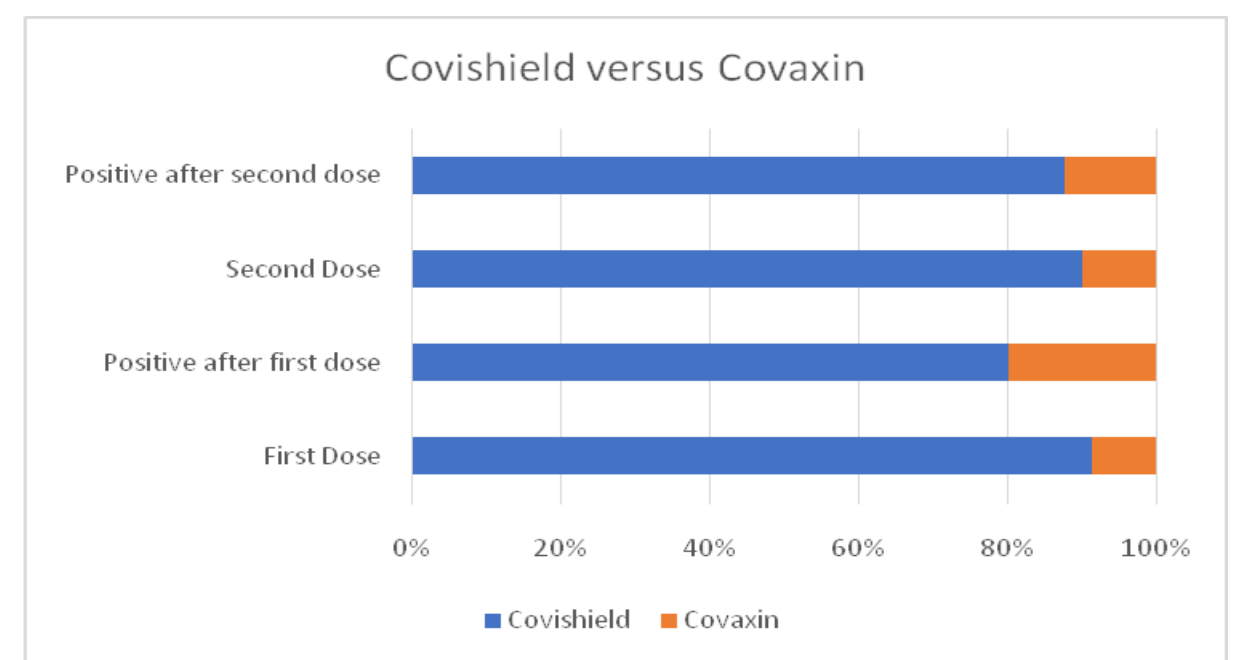

Graph 1: shows the comparison of Covishield versus Covaxin for the number of individuals vaccinated with first and dose and the number of cases positive after first and second doses as per the report of MOFHW till $20^{\text {th }}$ April 2021.

Another challenge after vaccination is experiencing side effects, which could be local or systemic. After vaccination, the common side effects experienced by individuals most commonly include injection site reactions such as pain, redness, and swelling. Other side effects include fever, headache, chills, nausea, feeling of sickness, fatigue, and enlargement of lymph nodes. Oral side effects include blisters, halitosis, ulcers, angular cheilitis, bleeding gingiva, tongue tingling, taste disturbances, vesicles, xerostomia, presence of white or red plaque, and swollen $\operatorname{lips}^{15}$.The comparison of side-effects of Sputnik V, Moderna, Pfizer-BioNTech, Covaxin, and Covishieldis shown in Table $3^{16-18}$.

Table 3: showing comparison of side-effects of Sputnik V, Moderna, Pfizer-BioNTech, Covaxin, and Covishield

\begin{tabular}{|c|c|c|c|c|}
\hline Sputnik V & Moderna & Pfizer-BioNTech & Covaxin & Covishield \\
\hline $\begin{array}{ll}\text { - } & \text { Headache } \\
\text { - } & \text { Fatigue } \\
\text { - } & \text { Pain at } \\
& \text { Injection Site } \\
\text { - } & \text { Flu like illness }\end{array}$ & $\begin{array}{ll}\text { - } & \text { Fever } \\
\text { - } & \text { Chills } \\
\text { - } & \text { Redness at } \\
& \text { Injection Site } \\
\text { - } & \text { Swelling at } \\
& \text { Infection Site }\end{array}$ & $\begin{array}{ll}\text { - } & \text { Headache } \\
\text { - } & \text { Myalgia } \\
\text { - } & \text { Arthralgia } \\
& \text { Injection Site } \\
& \text { Pain } \\
\text { - } & \text { Fatigue } \\
\text { - } & \text { Chills } \\
\text { Fever }\end{array}$ & $\begin{array}{ll}\text { - } & \text { Redness, Swelling, Pain at } \\
& \text { the Injection Site } \\
\text { - } & \text { Fever } \\
\text { - } & \text { Sweating and/or Chills } \\
\text { - } & \text { Malaise, Body ache } \\
\text { - } & \text { Nausea and Vomiting } \\
\text { - } & \text { Itching and Rashes } \\
\text { - } & \text { Headache }\end{array}$ & $\begin{array}{ll}\text { - } & \text { Pain at the } \\
& \text { Injection site } \\
\text { - } & \text { Redness } \\
\text { - } & \text { Moderate or high } \\
\text { fever } \\
\text { - } & \text { Drowsiness and } \\
& \text { Lethargy } \\
\text { - } & \text { Arm stiffness } \\
\text { - } & \text { Body ache and } \\
\text { pain }\end{array}$ \\
\hline
\end{tabular}

The side effects in adults after the second dose of Moderna vaccine, PfizerBioNTech vaccine, and Johnson \& Johnson vaccine are shown in Graph 2 as per the data collected from trials by U.S. Centres for Disease Control and Prevention ${ }^{19}$ 


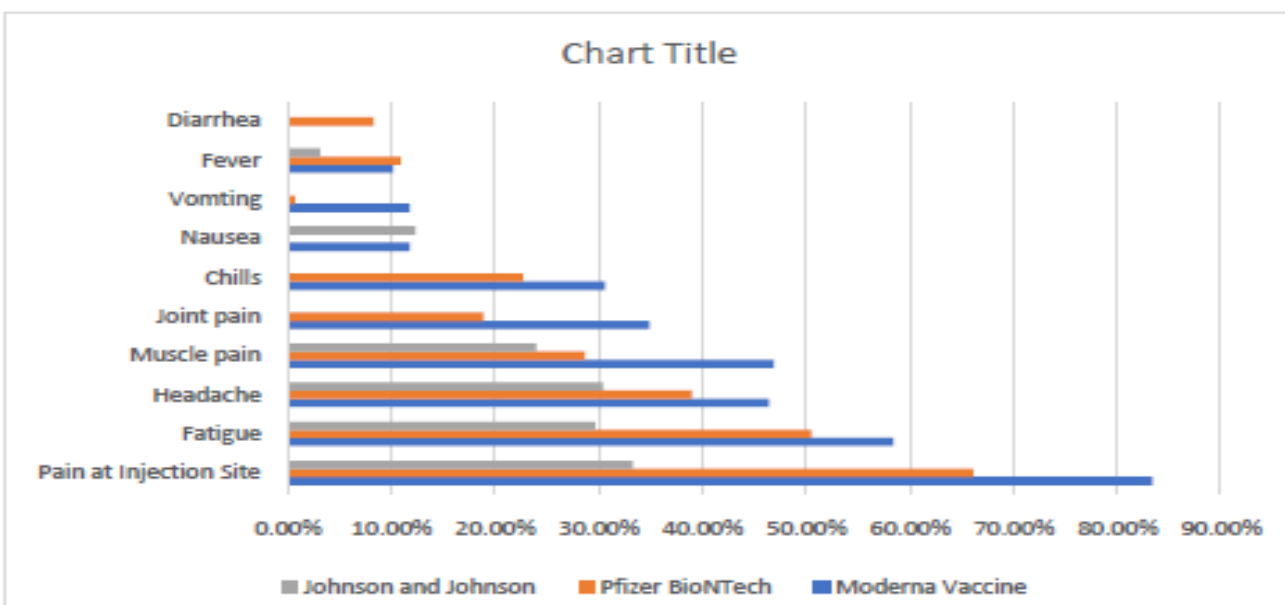

Graph 2: shows comparison of side effects of Johnson and Johnson, Pfizer BioNTech, and Moderna Vaccine after second dose

\section{Rare side effects of COVID Vaccine ${ }^{20}$}

The severe side effects experienced is shown in Figure 3.
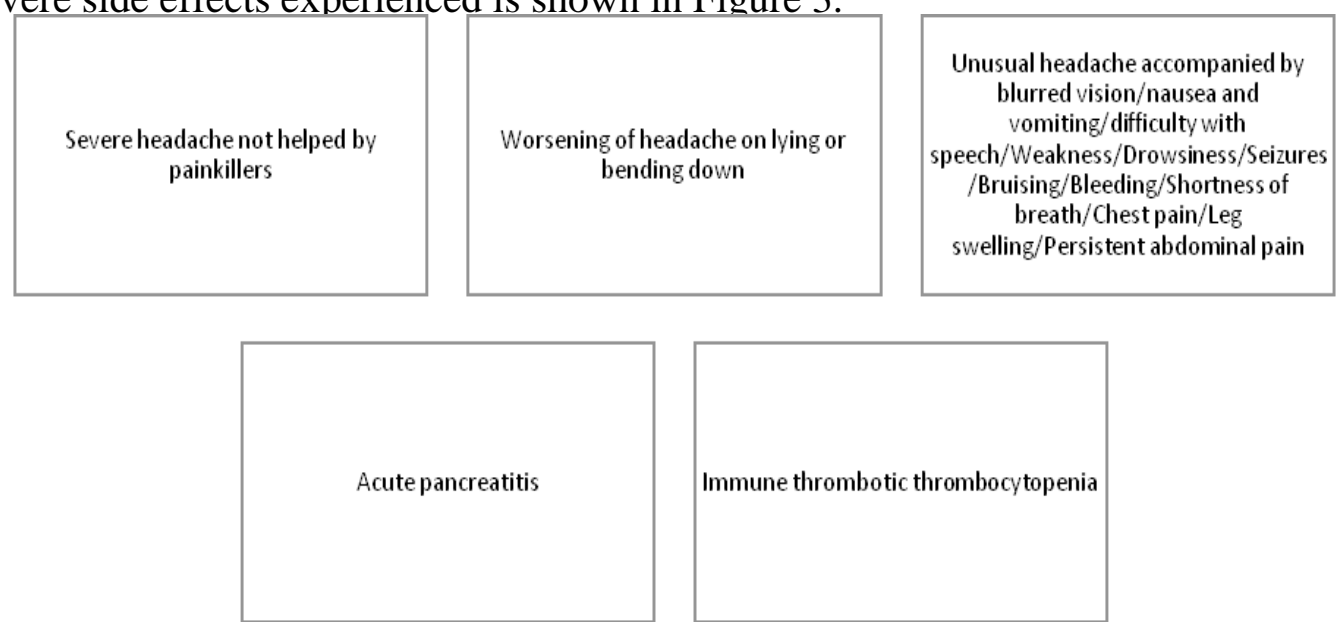

Figure 3: shows the rare/severe side-effects due to COVID Vaccine

\section{The Debate regarding Antibody Dependent Enhancement}

No ADE cases have been reported related to the COVID vaccine during the preclinical animal studies and human clinical trials. So far, there is no clear evidence that ADE may or may not be involved in the immunopathological processes associated with COVID-19 or reinfection with different variants after recovery or post-vaccination ${ }^{21}$. More studies are required to understand the correlation of protection against SARS-CoV-2 in natural human infection and as vaccines and antibodies in humans.

\section{CONCLUSION}

There is a constant comparison of the COVID vaccines which are coming out in the healthcare market. Several types of vaccines are available mainly, including mRNA, viral vectors, inactivated virus, and protein subunit on the majority. To better understand COVID vaccines, it is crucial to know how these vaccines work, their advantages and disadvantages, and what side effects can occur after vaccination? Despite the COVID vaccine data being promising, there is still a debate going on towards antibody dependent enhancement. We still need to have more studies to have better clarity regarding these challenges.

Acknowledgement: None

Declaration of Interest: None

Source of Funding: None 


\section{REFERENCES}

1. Satarker S, Nampoothiri M. Structural Proteins in Severe Acute Respiratory Syndrome Coronavirus-2. Arch Med Res. 2020; 51(6):482-491. doi: 10.1016/j.arcmed. 2020.05 .012

2. Jain S, Batra H, Yadav P, Chand S. COVID19 Vaccines Currently under Preclinical and Clinical Studies, and Associated Antiviral Immune Response. Vaccines (Basel). 2020 Nov 3;8(4):649. doi: 10.3390/vaccines 8040649. PMID: 33153096; PMCID: PMC7711779.

3. Clem AS. Fundamentals of vaccine immunology. J Glob Infect Dis. 2011;3 (1):73-78. doi:10.4103/0974-777X.77299

4. Astuti I, Ysrafil. Severe Acute Respiratory Syndrome Coronavirus 2 (SARS-CoV-2): An overview of viral structure and host response. Diabetes MetabSyndr. 2020; 14 (4):407412.doi:10.1016/j.dsx.2020.04. 020

5. Calina D, Sarkar C, Arsene AL, et al. Recent advances, approaches and challenges in targeting pathways for potential COVID-19 vaccines development. Immunol Res. 2020;68(6):315-324.doi:10.1007/s12026-02009154-4

6. Su S, Du L, Jiang S. Learning from the past: development of safe and effective COVID-19 vaccines. Nat Rev Microbiol. 2021 Mar; 19(3):211-219. doi: 10.1038/s41579-02000462-y. Epub 2020 Oct 16. PMID: 33067570; PMCID: PMC7566580.

7. Rodriguez-Coira J, Sokolowska M. SARSCoV-2 candidate vaccines-composition, mechanisms of action and stages of clinical development. Allergy. 2020 Dec 19. doi: 10.1111/all.14714. Epub ahead of print. PMID: 33340417.

8. Awadasseid A, Wu Y, Tanaka Y, Zhang W. Current advances in the development of SARS-CoV-2 vaccines. Int J Biol Sci. 2021 Jan 1;17(1):8-19. doi: 10.7150/ijbs.52569. PMID: 33390829; PMCID: PMC7757035.

9. Kyriakidis NC, López-Cortés A, González EV, Grimaldos AB, Prado EO. SARS-CoV-2 vaccines strategies: a comprehensive review of phase 3 candidates. npj Vaccines. $2021 \mathrm{Feb}$ 22;6(1):1-7.

10. Versteeg, L.; Almutairi, M.M.; Hotez, P.J.; Pollet, J. Enlisting the mRNA Vaccine Platform to Combat Parasitic Infections. Vaccines 2019, 7,122. https://doi.org/ 10.3390/vaccines 7040122
11. Creech CB, Walker SC, Samuels RJ. SARSCoV-2 Vaccines. JAMA. 2021 Apr 6;325 (13):1318-20.

12. Kyriakidis NC, López-Cortés A, González EV, Grimaldos AB, Prado EO. SARS-CoV-2 vaccines strategies: a comprehensive review of phase 3 candidates. NPJ Vaccines. 2021 Feb 22;6(1):28.

13. https://cdsco.gov.in/opencms/export/sites/CD SCO_WEB/en/biotechver.pdf

14. https://www.health.govt.nz/system/files/docu ments/pages/COVID-19-vaccine-safety-andside-effects-questions-13042021.pdf

15. Riad, A.; Pokorná, A.; Attia, S.; Klugarová, J.; Košcík, M.; Klugar, M. Prevalence of COVID-19 Vaccine Side Effects among Healthcare Workers in the Czech Republic. J. Clin. Med. 2021, 10, 1428. https://doi.org/ $10.3390 / \mathrm{jcm} 10071428$

16. Kataria et al., A Real World Evaluation of the safety and immunogenicity of the Covishield vaccine, ChAdOx1 nCoV- 19 Corona Virus Vaccine (Recombinant) in Health Care Workers (HCW) in National Capital Region (NCR) of India: A preliminary report. medRxiv

17. Singh BR, Gandharva S, Gandharva R. COVID 19 vaccines and COVID Immunity. Infectious Disease Research. 2021

18. https://english.jagran.com/india/COVID19vaccines-covishield-vs-covaxin-vs-sputnik-vknow-their-efficiency-cost-and-possible-sideeffects-10026855

19. https://www.aarp.org/health/conditionstreatments/info-2021/older-people-COVIDvaccine.html

20. Cirioll N. Reported orofacial adverse effects of COVID-19 vaccines: The knowns and the unknowns. Journal of Oral Pathology and Medicine. 2021;50(4):424-7.

21. Arvin, A.M., Fink, K., Schmid, M.A. et al. A perspective on potential antibody-dependent enhancement of SARS-CoV-2. Nature 584, 353-363 (2020). https://doi.org/10.1038/s 41586-020-2538-8

How to cite this article: Deka S, Iram F, Hariharan N et.al. COVID-19 vaccines- a narrative review. International Journal of Science \& Healthcare Research. 2021; 6(4): 99104. DOI: https://doi.org/10.52403/ijshr. 20211016 